\title{
Conservative Treatment of Large Lateral Cervical Discs Without Myelopathy; A One Year Follow-Up
}

\author{
MOHAMED MOHAMED, M.D.* and AHMED S.K. ABDELWAHED, M.D.** \\ The Department of Neurosurgery, Faculty of Medicine, Beni Sueif * and Cairo** Universities
}

\begin{abstract}
Background: The natural history of cervical disc prolapse is not fully known and clear indications for operative intervention, apart from evident weakness or radiological evidence of cord injury, cannot be established from the literature.

Several studies have shown that the largest lumbar disc appear to have the greatest tendency to resolve but there are not enough studies about prolapsed cervical discs.

Aim of the Study: The aim of this study was to investigate whether large lateral cervical prolapsed discs without myelopathy can be safely managed conservatively leading to clinical \& radiological improvement.

Patients and Methods: Twenty-four patients were studied by clinical assessments and magnetic resonance imaging (MRI) over the period of one year through which they received intermittent medical treatment (tizanidine, celecoxib, pregabalin).
\end{abstract}

All patients had severe brachialgia at first presentation, but began to show clinical improvement despite the large lateral disc herniations evident on initial imaging. Clinical assessment was done by neurological appraisal. The karnofsky performance Scale was used to measure function and changes in function. Repeat MRI studies every six months allowed measurement of volume changes of the herniated disc material.

Results: Initial follow up at three and six months showed positive response in twenty two patients (91.6\%). Follow-up at an average of 12 months revealed that twenty-one patient $(87.5 \%)$ had a complete and sustained recovery. Only threepatients had unsatisfactory progress and required discectomy. The average karnofsky performance score improved from $60 \%$ to $90 \%$.

Volumetric analysis of serial MRI scansfound an average reduction of $50 \%$ in disc size. There was poor correlation between clinical improvement and the extent of disc resolution.

Conclusion: A large lateral cervical disc herniation treatedconservatively can pursue a favorable clinical course. If early progress is shown, the long-term prognosis is very good and even large disc herniations can be treated conservatively.

Key Words: Cervical disc-Conservative - Pain.

Correspondence to: Dr. Mohamed Mohamed, The Department of Neurosurgery, Faculty of Medicine, Beni Sueif University

\section{Introduction}

CERVICAL pain together with brachialgia is a commonailment during which the majority of patients respond to conservative management. What constitutes conservative therapy and how long it should be administered are debatable [1,2]. The percentage of individuals who will respond positively to conservative measures over a given period of time is also unclear. Aiming to answer these questions, we offered medical treatment in combination with cervical collar therapy as an option for patients with cervical radiculopathy who presented for neurosurgical evaluation [3,4]. We then retrospectively reviewed their records to determine what percentage responded to these conservative measures. Several studies have shown that the largest lumbar disc appear to have the greatest tendency to resolve but there are not enough studies about prolapsed cervical discs [5,6,7]. The aim of this study was to investigate whether large lateral cervical prolapsed discs without myelopathy can be safely managed conservatively leading to clinical $\&$ radiological improvement $[\mathbf{8 , 9 , 1 0 ]}$.

\section{Patients and Methods}

Twenty-four patients were managed between 2012 and 2013 in Cairo University Hospitals \& Beni Sueif University Hospital.

\section{Inclusion criteria:}

- Symptoms by history and physical examination include neck pain, cervical radiculopathy.

- Radiographically determined single level discogenic origin (Disc herniation on MRI).

- The patient refused surgery and opted for conservative management.

- Single level Cervical discs. 
Exclusion criteria:

- Non-discogenic source of symptoms e.g. tumor and OPLL.

- Mylopathy.

- Neurological deficit.

- Multiple level cervical discs.

Patients were subjected to:

- History taking.

- General and neurological examination focusing on motor and sensory examination.

Investigations: pre-operative MRI cervical spine (T 1 and T2 images, axial and sagittal views), plain $\mathrm{x}$-ray cervical spine (A.P. view, lateral view in neutral position and lateral views in full flexion and extension) $+/-$ CT of the cervical spine.

Twenty-four patients were studied by clinical assessments and serial magnetic resonance imaging (MRI) over one year through which they received intermittent medical treatment (tizanidine, clecoxib, pregabalin).

Patients had severe brachialgia at first, but began to show clinical improvement on three and six months follow-up despite the large disc herniations. Clinical assessment was done by neurological appraisal. The karnofsky performance Scale was used to measure function and changes in function. Repeat MRI studies every six months allowed measurement of volume changes of the herniated disc material.

\section{Results}

During the study period, 24 patients with cervical radiculopathy. There were 10 females and 14 males. The mean age was 47 years. 12 patients suffered C5-6 disc 7 patient suffered C6-7 disc 4 patient suffered $\mathrm{C} 4-5$ and one patients suffered C3-4 disc. Initial follow-up at three and six months revealed that twenty two patients $(91.6 \%)$ showed improvement, further follow-up at an average of 12 months revealed that twenty-one patients $(87.5 \%)$ had a complete and sustained recovery. Only three patients required a discectomy. The average karnofsky performance score improved from $60 \%$ to $90 \%$.

Volumetric analysis of serial MRI scans found an average reduction of $20 \%$ in disc size. There was poor correlation between clinical improvement and the extent of disc resolution.
21 cases were considered therapeutic successes; patients experienced good relief of their arm pain within 2 to 6 weeks after initiation of medical treatment. Three cases were therapeutic failures and underwent cervical discectomy.

22 patients were able to return to work after 46 weeks, 5 patients showed relapse of symptoms after 6 months and at the end only 3 patients had unsatisfactory outcome of conservative management. So recurrence of symptoms and repeat of medical treatment trail can be done with total improvement in the end.

\section{Discussion}

Neck and arm pain are among the commonest symptoms affecting as much as $50 \%$ of normal individuals sometime during their lives; in most cases, these symptoms will respond to conservative management $[4,6]$. Not all of these patients will have experienced cervical radiculopathy because the differential diagnosis includes many other disease entities. Additionally although surgery is recommended only to those patients in whom conservative management has failed in most surgical series, The natural history of cervical radiculopathy is difficult to identify. The percentage of patients with nerve root compression-related cervical radiculopathy who will improve spontaneously at given periods of time after onset of symptoms is not known [7,8]. In 1972, DePalma, et al., [3], in an attempt to delineate the natural history, studied 68 patients who were managed by conservative therapy and who refused surgery although it was recommended; these 68 cases were compared with 281 cases in which surgery was performed. Surgically treated patients were off work for a mean of 10-12 weeks whereas $68 \%$ of non-surgically treated patients had returned to work within 4-6 weeks. Lees and Turner 11 studied patients with cervical spondylosis, in 51 cases who had no evidence of myelopathy, to clarify the natural history and prognosis of the disease. Of the 41 patients in the group who underwent follow-up for 2 to 10 years, 19 reported no further trouble, 12 experienced slight intermittent symptoms, and 10 suffered moderate disability. Only one patient suffered a severe episode of symptoms after the first occurrence $[4,5,6]$. The number of patients with radiculopathy was unclear, and the incidence of nerve root compression was not documented. Because the natural history of cervical radiculopathy is so ill defined, evaluation of various treatments, both conservative and surgical, is difficult [10]. 
The standard conservative management for cervical radiculopathy has included cervical collar therapy for immobility as well as analgesic agents, pain medications, \& muscle relaxants and physiotherapy.

Studies performed to evaluate the various conservative measures for treatment of supposed cervical radiculopathy have had significant methodological problems; in none of them has nerve root compression been documented, and neurological findings were not well described. For example, Martin and Corbin studied 61 patients with presumed cervical radiculopathy treated by conservative management found that $67.2 \%$ experienced definite improvement at early follow-up and $77.2 \%$ experienced definite improvement at late followup $[3,5,6]$

With regard to conservative treatment of cervical radiculopathy, all of our patients had welldocumented clinical evidence of cervical radiculopathy. All patientshad cervical MR imaging documenting nerve root compression, primarily caused by herniated cervical discs [9]. The mean duration of symptoms prior to consultation was approximately 3 weeks, and in $87.5 \%$ of the patients symptoms had been present for greater than 4 weeks; additionally all patients had undergone some form of conservative treatment. We believe that because of these treatment factors, we can draw some conclusions that may benefit patients with cervical radiculopathy $[\mathbf{7 , 8}]$. Because many of our patients had undergone a trial of conservative therapy lasting 4 to 6 weeks, they would have been considered possible candidates for surgery. Obviously patients would like to know, in addition to the success rate and complication rate, their chances for improving with additional conservative treatment. Because we had no control individuals, we cannot say that the patients would not have gotten better if they had not undergone collar therapy and cervical traction $[\mathbf{1 0 , 1 1 ]}$

It would appear, however, that we can realistically state that of patients with an approximate 6week history of cervical radiculopathy treated by a variety of measures, who then undergo analgesic physiotherapy for additional 2 to 3 weeks, approximately $87.5 \%$ will experience resolution of their radicular pain. We believe that presenting this information is important when discussing treatment options with patients [9-12]

\section{Conclusion:}

A large lateral cervical disc herniation treated conservatively can pursue a favorable clinical course. If early progress is shown, the long-term prognosis is very good and even large disc herniations can be treated conservatively.

\section{References}

1- RHEE J.M. and RIEW KD.: Evaluation and management of neck pain, radiculopathy, and myelopathy. Seminars. Spine Surgery, 17: 174-185, 2015.

2- BRAVERMAN D.L., SLIPMAN C.W. and LENROW D.A.: Using gabapentin to treat cervical radicolopathy Arch. Phys. Med. Rehabil., 82: 691-693, 2011.

3- MALONE D.G., BALDWIN N.G. and TOMECEK F.J.: Complications of cervical spinemanipulation therapy: 5year retrospective study in a single-group practice. Neurosurg Focus, 2002; 13: ecp1, 2012.

4- M. SASSO RCMACDAEG K., NORDMANN D. and SMITH M.: Selective nerve root injectionscan predict surgical outcome for lumbar and cervical radiculopathy: Comparison to magnetic resonance imaging. J. Spinal. Disord. Tech., 18: 471-478, 2015.

5- ROSENKRANZ M.,GRZYSKA U. and NIESEN W.: Anterior spinal artery syndrome following periradicular cervical nerve root therapy. J. Neurol., 251: 229-231, 2004.

6- RHEE J.M., PARK J.B., YANG J.Y. and RIEW D.K. Indications and techniques for anteriorcervical plating. Neurol. India., 53: 433-439, 2005.

7- HACKER R.J. and MILLER: Failed anterior cervical foraminotomy. J. Neurosurg., 98 (2 Suppl): 126-130, 2013.

8- DE PALMA A.F., ROTHMAN R.H. and LEVITT: The natural history of severe cervical disc degeneration. Acta. Orthop. Scand., 43: 392-396, 1972.

9- ZEIDMAN S.M. and DUKER T.B.: Posterior cervical laminoforaminotomy for radiculopathy: Review of 172 cases. Neurosurgery, 33: 356-362, 1993.

10- LEESE F. and TURNER J.W.A.: Natural history and prognosis of cervical spondylosis. BMJ. Dec., 28: 16071610,1963

11- MATTIN G.M. and CORBIN K.B.: An evaluation of conservative treatment for patients with cervical disk syndrome. Staff. Meet. Mayo. Clin., 29: 324-326, 1954.

12- PARK J.B., CHO Y.S. and RIEW K.D.: Development of adjacent-level ossification inpatients with an anterior cervical plate. J. Bone. Joint. Surg. Am., 87: 558-563, 2015. 


\section{العلاج التخفظى لحالات الأنزلاق الغضروفى العنقى الكبيرة بلدون تأثر

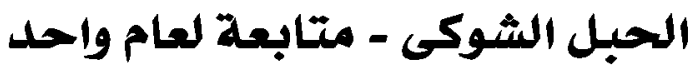

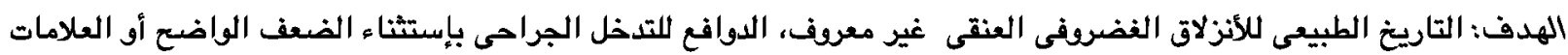

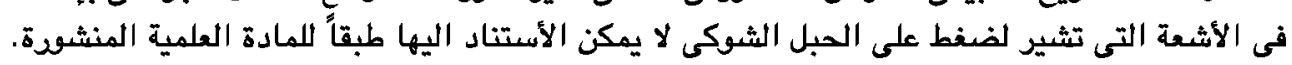

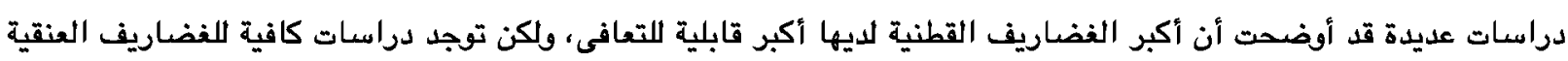

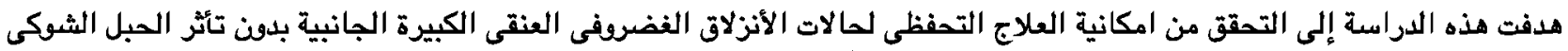
بطريقة تؤدى للتحسن الإكلينيكى وتحسن صودة المكانية الأشعة اليضاً.

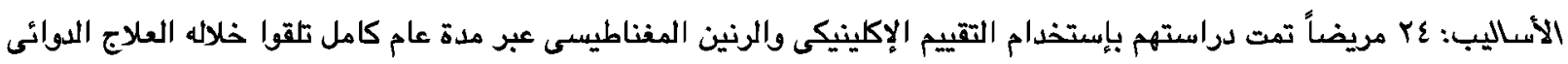
لفترات متقطعة بإستخدام ( تيزانيدين ، سيليكوكسيب ، بريجابلين).

كل المرضى كان لديهم آلام شليدة بالذراع فى البداية، ولكن بدأوا في إظهار التصسن الإكينيكى على الرغم من الأنزلاق الفضروفى العنقى الجانبى الكبير الواضح فى الفحوصات المبدئية بالأشعة.

التقييم الإ كلينيكى تم بإستخدام الكثف الإ كلينيكى للأعصاب، تم بإستخدام مقياس كارنوفسكى لقياس الوظيفة والتغير فيها، تم إجراء متابعة بالرنين المغناطيسى كل ستة اشهر أتاحت قياس تغير الإني لإنم الجزءء المنزلق بالغضروف.

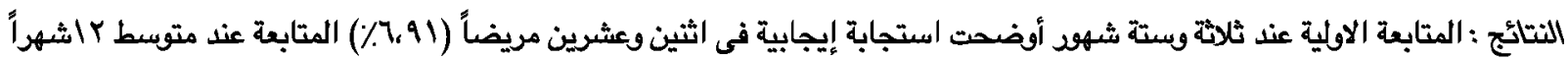

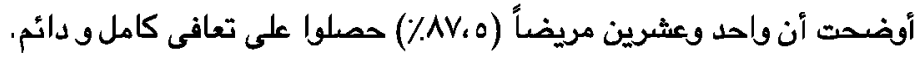

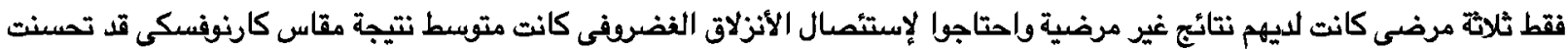

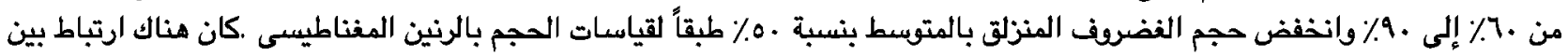
تراجع حجم الفضروف والتحسن الإ كلينيكى . الخلاصة: الأنزلاق الغضروفى العنقى الجانبى الكبير ممكن علاجة تحفظياً لنتائج مرضية، عند ما تحدث استجابة مبكرة فإن النتجة على

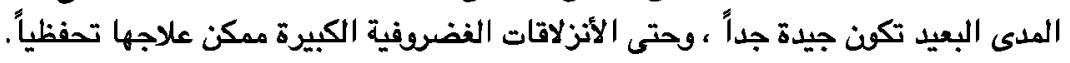

